\title{
Antidiarrhoeal activity of Psidium guajava Linn. (Myrtaceae) leaf aqueous extract in rodents
}

\author{
John A.O. OJEWOLE ${ }^{1}$, Emmanuel O. AwE ${ }^{1}$ and \\ Witness D.H. CHIWORORO ${ }^{1}$ \\ ${ }^{1}$ Department of Pharmacology, School of Pharmacy \& Pharmacology, Faculty of Health \\ Sciences, University of KwaZulu-Natal
}

Received September 28, 2008; Accepted October 21, 2008

\begin{abstract}
The leaf of Psidium guajava Linn. (family: Myrtaceae) is used traditionally in African folk medicine to manage, control and/or treat a plethora of human ailments, including diarrhoea. In this study, we examined the antidiarrhoeal activity of Psidium guajava leaf aqueous extract (PGE) on experimentally-induced diarrhoea in rodents. PGE (50-400 $\mathrm{mg} / \mathrm{kg}$ p.o. $)$ produced dose-dependent and significant $(P<0.05-0.01)$ protection of rats and mice against castor oil-induced diarrhoea, inhibited intestinal transit, and delayed gastric emptying. Like atropine $(1 \mathrm{mg} / \mathrm{kg}$, p.o. $)$, PGE produced dose-dependent and significant $(P<0.05-0.01)$ antimotility effect, and caused dose-related inhibition of castor oil-induced enteropooling in the animals. Like loperamide $(10 \mathrm{mg} / \mathrm{kg}$, p.o. $)$, PGE dosedependently and significantly $(P<0.05-0.01)$ delayed the onset of castor oil-induced diarrhoea, decreased the frequency of defaecation, and reduced the severity of diarrhoea in the rodents. Compared with control animals, PGE dose-dependently and significantly $(P<0.05-0.01)$ decreased the volume of castor oil-induced intestinal fluid secretion, and reduced the number, weight and wetness of faecal droppings. PGE also produced concentration-related and significant $(P<0.05-0.01)$ inhibitions of the spontaneous, rhythmic, pendular contractions of the rabbit isolated duodenum. The findings of this study indicate that PGE possesses antidiarrhoeal activity, and thus lend pharmacological credence to the suggested folkloric use of the plant as a natural remedy for the treatment, management and/or control of diarrhoea in some rural communities of southern Africa.
\end{abstract}

Key words: Psidium guajava, leaf aqueous extract, antidiarrhoeal activity

\section{Introduction}

Since ancient times, diarrhoea has been recognized as one of the most important health problems afflicting mankind, particularly those populations in socio-economically backward, and developing, third-world countries. Globally, diarrhoea has been estimated to kill about 2.2

Correspondence to: Prof. John A.O. Ojewole, Department of Pharmacology, School of Pharmacy \& Pharmacology, Faculty of Health Sciences, University of KwaZulu-Natal, Private Bag X54001, Durban 4000, South Africa

Phone: +27-31-260-7356/7767 Fax: +27-31-260-7907 e-mail: ojewolej@ukzn.ac.za 
million people annually, majority of whom are infants and children below the age of 5 years (Venkatesan et al., 2005; Gutiěrrez et al., 2008). Diarrhoea is a disorder characterized by discharge of semisolid or watery faecal matter from the bowel three or more times in a day (Hirchhorn, 1980; Snyder and Merson, 1982; Suleiman et al., 2008; Mbagwu and Adeyemi, 2008). It involves an increase in the fluidity, volume and frequency of bowel movements, increased frequency of bowel sound, wet stools and abdominal pain, accompanied by increased secretion and decreased absorption of fluid, and thus loss of water and electrolytes (Fontaine, 1988; Field et al., 1989; Avery and Synder, 1990; Longe and Dipiro, 1992). Generally, the treatment of diarrhoea is non-specific, and is usually aimed at reducing the discomfort and inconvenience of frequent bowel movements (Brunton, 1996; Suleiman et al., 2008). In order to overcome the menace of diarrhoea in developing countries, especially the discomfort and inconvenience of frequent bowel movements, the World Health Organization (WHO) has introduced a programme for diarrhoeal control which involves the use of traditional herbal medicines. Several African medicinal plants have been reported to be useful in the treatment, management and/or control of diarrhoea (Abdullahi et al., 2001; Aniagu et al., 2005; Agunu et al., 2005; Suleiman et al., 2008; Adeyemi and Akindele, 2008; Mbagwu and Adeyemi, 2008). As a part of our broad-based search for African medicinal plants with antidiarrhoeal properties, the present study was undertaken to examine the possible usefulness of Psidium guajava Linn. leaf aqueous extract (PGE) in the treatment, management and/or control of diarrhoea.

Psidium guajava Linn. (family: Myrtaceae) is a shrub or a small spreading tree of $3-5 \mathrm{~m}$ in height. The bark peels off in large thin flakes, revealing the characteristically smooth, palecoloured trunk and branches (Van Wyk et al., 2002; Van Wyk and Wink, 2004). The large leaves are simple, opposite, oblong, elliptic or ovate with prominent veins, especially on the lower side. The leaves are arranged in pairs on four-angled twigs, elliptical or oblong, 5-12 cm long and 3$5 \mathrm{~cm}$ wide; consisting of obtuse or micronulate apex; margin entire or slightly curved; with broadly obtuse base; blade with more-or-less hairy beneath; the veins are parallel and conspicuously raised below; with petioles of $4-8 \mathrm{~mm}$ long. The flowers are white, axillary, solitary or 2-3 together on slender peduncles, about $3 \mathrm{~cm}$ in diameter; consisting of calyx-tube campanulate, deeply divided into $4-5$ lobes above the ovary. The many-seeded, usually yellow fruit is rounded, globose or pear-shaped, tipped with remnants of the calyx lobes (Van Wyk et $a l ., 2002$; Van Wyk and Wink, 2004). The fruit pulp is white or pink and juicy, containing many small, hard seeds. Mature fruits of P. guajava possess delicious taste and are rich in vitamin C (Van Wyk et al., 2002).

Although a native of Central America, . guajava has become naturalized in many countries, and now has a wide distribution throughout tropical and subtropical parts of the world, including South Africa. In South Africa, P. guajava leaves are traditionally used for a variety of human ailments, including the management, control and/or treatment of diarrhoea, dysentery, fever, cough, ulcers, boils and wounds, malaria, painful arthritic and other inflammatory conditions, as well as for diabetes mellitus (Van Wyk et al., 2002; Van Wyk and Wink, 2004). The present study was prompted by the claim of some South African traditional health practitioners that decoctions and infusions of $P$. guajava leaves are effective remedies for the management and/or control of diarrhoea. The core aim of the present study was, therefore, to examine the 
antidiarrhoeal activity of $P$. guajava leaf aqueous extract in rodents.

\section{Materials and methods}

\section{Ethical considerations}

Experimental procedures and protocols used in this study were approved by the Ethics Committee of the former University of Durban-Westville, Durban 4000, South Africa; and conform to the "Guide to the care and use of animals in research and teaching" (published by the University of Durban-Westville, Durban 4000, South Africa).

\section{Plant material}

Fresh leaves of Psidium guajava Linn. (family: Myrtaceae) (locally known as 'guava' in English, and 'ugwava' in isiZulu language of South Africa) were collected on the Westville Campus of the University of KwaZulu-Natal, Durban, South Africa, between January and June 2006. The leaves were identified by the Taxonomist/Curator of the former University of Durban-Westville's Department of Botany as those of Psidium guajava Linn. (family: Myrtaceae). Voucher specimen of the plant has been deposited in the Herbarium of the University's Botany Department.

\section{Preparation of Psidium guajava leaf aqueous extract}

One kilogramme $(1 \mathrm{~kg})$ of Psidium guajava fresh leaves were air-dried at room temperature. The air-dried leaves of the plant were milled into fine powder in a Waring commercial blender. The powdered leaf was macerated in distilled water and extracted twice, on each occasion with 2.51 of distilled water at room temperature $\left(27 \pm 1^{\circ} \mathrm{C}\right)$ for 48 hours (with occasional shaking). The combined aqueous extract solubles were concentrated to dryness under reduced pressure at $60 \pm 1^{\circ} \mathrm{C}$ in a rotary evaporator. Freeze-drying and solvent elimination of the resulting aqueous extract finally gave $24.83 \mathrm{~g}$ (i.e., $2.483 \%$ yield) of a light brown, powdery crude $P$. guajava leaf aqueous extract (PGE). Without any further purification, aliquot portions of the plant's crude extract residue were weighed and dissolved in distilled water (at room temperature) for use on each day of our experiments.

\section{Animals}

Healthy, male and female Balb C mice (Mus domesticus) weighing 20-25 g, and healthy young adult, Wistar rats (Rattus norvegicus) of both sexes weighing 250-300 g, were used. The animals were kept and maintained under laboratory conditions of temperature, humidity, and light; and were allowed free access to food (standard pellet diet) and drinking tap water ad libitum. The animals were divided into plant extract- and reference drug-treated 'test', and distilled water-treated 'control' groups of 8-10 animals per group. All the animals were fasted for 16 hours, but still allowed free access to tap water, before the commencement of our experiments. 


\section{Acute toxicity testing}

The median lethal dose $\left(\mathrm{LD}_{50}\right)$ of PGE was determined in the mice, using a modified method of Lorke (1983). Mice fasted for 16 hours were randomly divided into groups of 8 mice per group. Graded doses of PGE (50, 100, 200, 400, 800, 1,600 and 3,200 mg/kg) were separately administered intraperitoneally $(i . p$.$) to the mice in each of the 'test' groups. Each of the mice in$ the 'control' group was treated with distilled water $(10 \mathrm{ml} / \mathrm{kg}$, i.p. $)$ only. The mice in both the 'test' and 'control' groups were then allowed free access to food and water, and observed over a period of 48 hours for signs of acute toxicity. The number of deaths (caused by the extract) within this period of time was noted and recorded. Log dose-response plots were constructed for the plant's extract, from which the median lethal dose $\left(\mathrm{LD}_{50}\right)$ of the leaf aqueous extract was determined.

\section{Evaluation of antidiarrhoeal activity of PGE}

1. Castor oil-induced diarrhoea in rats

Diarrhoea was induced in rats by oral administration of castor oil $(3 \mathrm{ml} / \mathrm{kg}$, p.o. $)$ as previously described by Awouters et al. (1978), Mukherjee et al. (1998), Aniagu et al. (2005), Suleiman et al. (2008) and Mbagwu and Adeyemi (2008), with some modifications. Before the commencement of our experiments, the rats used were fasted for 16 hours (during which time the animals were given free access to drinking tap water ad libitum) and randomly allocated into six groups of 6 rats per group. Each rat was subsequently separately placed in a plastic cage lined at the bottom with a transparent sheet. Group 1 rats were individually treated with $10 \mathrm{ml} /$ $\mathrm{kg}$ (p.o.) of distilled water (the vehicle in which PGE and loperamide were dissolved) only. Groups 2-5 rats received $10 \mathrm{ml} / \mathrm{kg}$ (p.o.) of Psidium guajava leaf aqueous extract equivalent to PGE doses of 50, 100, 200 and $400 \mathrm{mg} / \mathrm{kg}$, respectively. Group 6 rats were individually treated with $10 \mathrm{mg} / \mathrm{kg}$ (p.o.) of loperamide, a standard antidiarrhoeal agent. Thirty minutes after oral pretreatment of the animals with distilled water, doses of PGE and loperamide, each rat in each of the six groups was given $3 \mathrm{ml} / \mathrm{kg}$ of castor oil orally. Thereafter, the animals were observed for 6 hours for the presence of characteristic diarrhoeal droppings. The following parameters were observed: the time elapsed between the administration of castor oil and the excretion of the first diarrhoeic faeces, the total number of faecal output and the number of diarrhoeic stools excreted by each animal in 6 hours, as well as the total weight of the diarrhoeic faeces in that period of time. Severity of the castor oil-induced diarrhoea was noted and recorded as scores. A numerical score based on stool consistency, using the method of Dicarlo et al. (1994), was assigned as follows: normal stool (or lack of diarrhoea)=1, semi-solid stool=2, and watery stool/ faeces $=3$, respectively. The corresponding percentages and purging indices were calculated, the later by comparison with the control group of rats. The in vivo antidiarrhoeal index ( $\mathrm{ADI}$ in vivo $)$ was thereafter calculated according to the formula described in detail earlier by Aye-Than $e t$ al (1989), and Mbagwu and Adeyemi (2008). The onset of diarrhoea is measured as the time interval (in minutes) between the administration of castor oil and the appearance of the first diarrhoeic stool. The faecal matter was collected and weighed over the entire observation period of 6 hours. The changes in body weight between the pre- and post-experiment periods were also determined. Percentage inhibitions of defaecation score and faecal weight were 
calculated by using [control mean - treated (test) mean]/control mean $\times 100$ ].

2. Castor oil-induced enteropooling, intestinal transit and intestinal fluid in rats

As described above, the rats used were fasted for 16 hours (during which time the animals were given free access to drinking tap water ad libitum) and randomly allocated into six groups of 6 rats per group. Each rat in each group was subsequently separately placed in a plastic cage lined at the bottom with a transparent sheet. Group 1 rats were individually treated with $10 \mathrm{ml} /$ $\mathrm{kg}$ (p.o.) of distilled water (the vehicle in which PGE was dissolved) only. Groups 2-5 rats received $10 \mathrm{ml} / \mathrm{kg}$ (p.o.) of Psidium guajava leaf aqueous extract equivalent to PGE doses of 50, 100,200 and $400 \mathrm{mg} / \mathrm{kg}$, respectively, followed immediately by oral administration of $3 \mathrm{ml} / \mathrm{kg}$ of castor oil. Group 6 rats were individually treated with $10 \mathrm{mg} / \mathrm{kg}$ (p.o.) of loperamide, followed by oral administration of $3 \mathrm{ml} / \mathrm{kg}$ of castor oil. Thirty minutes following oral treatments of the animals with distilled water, graded doses of PGE, loperamide and castor oil, each animal in the six groups was given $3 \mathrm{ml} / \mathrm{kg}$ (p.o.) of $10 \%$ activated charcoal in physiological saline (i.e., $0.9 \% \mathrm{w} / \mathrm{v}$ sodium chloride solution). The intestinal transit and volume of intestinal fluid in the rats were then measured as described in detail by Dicarlo et al. (1994), with some modifications. Forty minutes after charcoal meal, the rats were anaesthetized by ether inhalation and euthanized by cervical dislocation. The abdomen of each rat was cut open, and the whole length of the intestine from the pylorus to the caecum was ligated, dissected and carefully removed. The distance of the charcoal plug from pylorus to caecum - i.e., peristaltic index (PI) which is the distance traveled by charcoal meal relative to the entire length of the small intestine - was determined and expressed as a percentage of the total length of the small intestine. The weight of the full intestine was determined. The intestinal content was expelled into a graduated measuring cylinder and its volume was determined. The weight of the empty intestine was taken, and the difference between the full and empty intestine was thus calculated. Percentage inhibitions of intestinal transit of the charcoal meal by loperamide $(10 \mathrm{mg} / \mathrm{kg}$, p.o. $)$ and PGE (50, 100, 200 and $400 \mathrm{mg} / \mathrm{kg}$, p.o.) were calculated as a function of the distilled water-treated negative 'control' by using the formula:

Percentage transit inhibition $=\left[\mathrm{T}_{0}-\mathrm{T}_{\mathrm{t}} / \mathrm{T}_{0}\right] \times 100$

where $T_{0}=$ mean length traversed by charcoal meal in distilled water-treated 'control' rats; and $\mathrm{T}_{\mathrm{t}}=$ mean length traversed by charcoal meal in PGE- and loperamide-treated 'test' rats.

3. Castor oil-induced enteropooling, intestinal transit and intestinal fluid in mice

Using adult Balb $\mathrm{C}$ mice of both sexes (25-30 g), the experimental procedures and protocols described in detail above were repeated. Percentage inhibitions of intestinal transit of the charcoal meal by loperamide (10 mg/kg, p.o.) and PGE (50, 100, 200 and $400 \mathrm{mg} / \mathrm{kg}$, p.o.) were calculated as a function of the distilled water-treated negative 'control' by using the formula:

Percentage transit inhibition $=\left[\mathrm{T}_{\mathrm{o}}-\mathrm{T}_{\mathrm{t}} / \mathrm{T}_{\mathrm{o}}\right] \times 100$

where $T_{0}=$ mean length traversed by charcoal meal in distilled water-treated 'control' mice; and 
$\mathrm{T}_{\mathrm{t}}=$ mean length traversed by charcoal meal in PGE- and loperamide-treated 'test' mice.

4. Gastrointestinal motility in mice (charcoal meal)

Balb $C$ adult mice of both sexes (weighing 25-30 g) were randomly divided into six groups of 6 mice each. Prior to the experiments, the mice were fasted for 16 hours (during which time the animals were given free access to drinking tap water ad libitum). Group 1 mice individually received distilled water $(10 \mathrm{ml} / \mathrm{kg}$, p.o. $)$ only, while Groups $2-5$ mice individually received 10 $\mathrm{ml} / \mathrm{kg}$ (p.o.) of Psidium guajava leaf aqueous extract equivalent to PGE doses of 50, 100, 200 and $400 \mathrm{mg} / \mathrm{kg}$, respectively. Group 6 mice were treated with atropine sulphate $(1 \mathrm{mg} / \mathrm{kg}$, p.o. $)$. Thirty minutes after distilled water, PGE, or atropine sulphate administration, each mouse was given $3 \mathrm{ml} / \mathrm{kg}$ of activated charcoal meal (10\% activated charcoal in normal saline) orally. The animals were subsequently anaesthetized by ether inhalation and euthanized by cervical dislocation 30 minutes later, and the abdomen opened. The small intestine of each mouse was dissected out from the pylorus to the caecum, and the total distance traversed by the charcoal plug along the small intestine was determined in both the 'control' and treated 'test' mice groups (Aniagu et al., 2005). For each animal group, the results were expressed as percentage of the distance traveled from the pylorus to the caecum (Gamaniel and Akah, 1996).

\section{Data and statistical analysis}

Data obtained are presented as means $( \pm$ S.E.M.) for the number of animals in each group $(n=6)$. Data obtained from distilled water-treated 'control' mice and rats were used as baseline values. In all cases, the results obtained from extract- and reference drug-treated 'test' animal groups were compared with those obtained from distilled water (vehicle)-treated 'control' animal groups. The differences between the data obtained from 'test' animal groups and the data obtained from vehicle-treated 'control' animal groups, were subjected to one-way analysis of variance (ANOVA; 95\% confidence interval), followed by Dunnett's post-hoc test (Dunnett and Goldsmith, 1993). In all cases, statistical significance was established at values of $P \leq 0.05$.

\section{Results}

\section{Acute toxicity study}

Intraperitoneal administrations of graded doses of Psidium guajava leaf aqueous extract in mice gave an $\mathrm{LD}_{50}$ value of $1,534 \pm 69 \mathrm{mg} / \mathrm{kg}$.

\section{Castor oil-induced diarrhoea in rats}

Three-and-a-half hours after oral castor oil administration, all the rats in the 'control' group of animals produced copious diarrhoea. Pretreatment of the rats (in the treated 'test' groups) with Psidium guajava leaf aqueous extract (PGE, 50, 100, 200 and $400 \mathrm{mg} / \mathrm{kg}$, p.o.) dosedependently and significantly $(P<0.05-0.01)$ delayed the onset of diarrhoea, reduced the frequency of defaecation and the wetness of the faecal droppings (reduction in the number of wet stools and total stools), and decreased the weight of wet stools and the general diarrhoea score, including the hard, mild and copious stools (Table 1). The standard antidiarrhoeal drug, 
Table 1. Effects of Psidium guajava leaf aqueous extract (PGE) on castor oil-induced diarrhoea in rats

\begin{tabular}{lccccc}
\hline $\begin{array}{c}\text { Treatment } \\
\text { group }\end{array}$ & $\begin{array}{c}\text { Dose } \\
(\mathrm{mg} / \mathrm{kg}, \text { p.o. })\end{array}$ & $\begin{array}{c}\text { Total number } \\
\text { of stools }\end{array}$ & $\begin{array}{c}\text { \% Rats with } \\
\text { diarrhoea }\end{array}$ & $\begin{array}{c}\text { Number of } \\
\text { wet stools }\end{array}$ & $\begin{array}{c}\text { \% Rats } \\
\text { protected }\end{array}$ \\
\hline $\begin{array}{r}\text { Control } \\
\text { (Distilled water) }\end{array}$ & & $12.6 \pm 4.1$ & 83.30 & $10.1 \pm 3.3$ & 0.0 \\
PGE & $50 \mathrm{mg} / \mathrm{kg}$ & $10.1 \pm 3.4$ & 66.70 & $9.3 \pm 3.2$ & 16.70 \\
PGE & $100 \mathrm{mg} / \mathrm{kg}$ & $7.4 \pm 2.5$ & 50.00 & $6.8 \pm 1.9$ & $50.00^{*}$ \\
PGE & $200 \mathrm{mg} / \mathrm{kg}$ & $5.3 \pm 1.6$ & 33.33 & $3.5 \pm 1.1$ & $66.70^{* *}$ \\
PGE & $400 \mathrm{mg} / \mathrm{kg}$ & $3.3 \pm 0.8$ & 16.70 & $2.3 \pm 0.27$ & $83.30^{* *}$ \\
Loperamide & $10 \mathrm{mg} / \mathrm{kg}$ & 0.0 & 0.00 & 0.0 & $100.00^{* * *}$ \\
One-way ANOVA + Dunnett's post-hoc test, $\mathrm{n}=6 .{ }^{*}, P<0.05 ;{ }^{* *}, P<0.01 ;{ }^{* * *}, P<0.001$ vs. control. Mean \\
\pm SEM.
\end{tabular}

Table 2. Effects of Psidium guajava leaf aqueous extract on normal intestinal transit in mice

\begin{tabular}{lrcc}
\hline $\begin{array}{c}\text { Treatment } \\
\text { group }\end{array}$ & $\begin{array}{c}\text { Dose } \\
(\mathrm{mg} / \mathrm{kg}, \text { p.o. })\end{array}$ & $\begin{array}{c}\text { \% Peristaltic } \\
\text { index }\end{array}$ & $\begin{array}{c}\text { \% Inhibition } \\
\text { of transit }\end{array}$ \\
\hline $\begin{array}{l}\text { Control } \\
\text { (Distilled water) }\end{array}$ & $50 \mathrm{mg} / \mathrm{kg}$ & 76.41 & 14.83 \\
PGE & $100 \mathrm{mg} / \mathrm{kg}$ & 64.12 & $28.53^{*}$ \\
PGE & $200 \mathrm{mg} / \mathrm{kg}$ & 41.33 & $53.93^{*}$ \\
PGE & $400 \mathrm{mg} / \mathrm{kg}$ & 20.47 & $77.18^{* *}$ \\
PGE & $10 \mathrm{mg} / \mathrm{kg}$ & 5.26 & $94.14^{* * *}$ \\
Loperamide & & \\
One-way ANOVA + Dunnett's post-hoc test, $\mathrm{n}=6$. & \\
${ }^{*}, P<0.05 ;{ }^{* *}, P<0.01 ;{ }^{* * *}, P<0.001$ vs. control.
\end{tabular}

loperamide $(10 \mathrm{mg} / \mathrm{kg}$, p.o. $)$, produced a more marked, significantly greater $(P<0.001)$ inhibitory effects on all the diarrhoeal parameters examined than the highest dose of PGE (400 $\mathrm{mg} / \mathrm{kg}$, p.o.) used (Table 1).

\section{Normal intestinal transit in mice}

In the 'control' group of mice, charcoal meal traversed the farthest distance of the total length of small intestine. In the Psidium guajava leaf aqueous extract-treated 'test' groups of mice, PGE (50, 100, 200 and $400 \mathrm{mg} / \mathrm{kg}$, p.o.) dose-dependently and significantly $(P<0.05-0.01)$ decreased the normal intestinal propulsive movement and transit of charcoal meal through the small intestine (Table 2$)$. Loperamide $(10 \mathrm{mg} / \mathrm{kg}$, p.o.) produced greater anti-motility effect than the highest dose of PGE (400 mg/kg, p.o.) used (Table 2).

\section{Castor oil-induced intestinal transit in rats}

In the 'control' group of rats used, charcoal meal traveled faster than in the 'control' group of mice used for the above normal intestinal transit study (see above). Thirty minutes after intra-gastric administration in the 'control' group of rats, the charcoal meal traversed $94.13 \%$ of the total length of the small intestine (Table 3). In the PGE-treated 'test' groups of rats, PGE (50, 100, 200 and $400 \mathrm{mg} / \mathrm{kg}$, p.o. $)$ dose-dependently and significantly $(P<0.05-0.01)$ decreased 
Table 3. Effects of Psidium guajava leaf aqueous extract on castor oilinduced intestinal transit in rats

\begin{tabular}{|c|c|c|c|}
\hline $\begin{array}{l}\text { Treatment } \\
\text { group }\end{array}$ & $\begin{array}{c}\text { Dose } \\
(\mathrm{mg} / \mathrm{kg}, \text { p.o. })\end{array}$ & $\begin{array}{l}\text { \% Peristaltic } \\
\text { index }\end{array}$ & $\begin{array}{c}\text { \% Inhibition } \\
\text { of transit }\end{array}$ \\
\hline $\begin{array}{l}\text { Control } \\
\text { (Distilled water) }\end{array}$ & & 94.13 & 0.00 \\
\hline PGE & $50 \mathrm{mg} / \mathrm{kg}$ & 74.36 & 21.00 \\
\hline PGE & $100 \mathrm{mg} / \mathrm{kg}$ & 51.43 & $45.36^{\star}$ \\
\hline PGE & $200 \mathrm{mg} / \mathrm{kg}$ & 26.81 & $71.52^{\star \star}$ \\
\hline PGE & $400 \mathrm{mg} / \mathrm{kg}$ & 11.55 & $87.73^{\star \star}$ \\
\hline Loperamide & $10 \mathrm{mg} / \mathrm{kg}$ & 4.04 & $95.71^{* * *}$ \\
\hline
\end{tabular}

Table 4. Effects of Psidium guajava leaf aqueous extract (PGE, 50-400 mg/kg, p.o.) on intestinal propulsion in mice (charcoal meal study)

\begin{tabular}{lccccc}
\hline $\begin{array}{c}\text { Treatment } \\
\text { group }\end{array}$ & $\begin{array}{c}\text { Dose } \\
(\mathrm{mg} / \mathrm{kg}, \text { p.o. })\end{array}$ & $\begin{array}{c}\text { Intestinal } \\
\text { length }(\mathrm{cm})\end{array}$ & $\begin{array}{c}\text { Distance traveled } \\
\text { by charcoal }\end{array}$ & $\begin{array}{c}\text { \% Peristaltic } \\
\text { index }\end{array}$ & $\begin{array}{c}\text { \% Inhibition } \\
\text { of motility }\end{array}$ \\
\hline $\begin{array}{c}\text { Control } \\
\text { (Distilled water) }\end{array}$ & & $41.5 \pm 1.40$ & $37.2 \pm 4.10$ & 91.32 & 0.00 \\
PGE & $50 \mathrm{mg} / \mathrm{kg}$ & $40.8 \pm 1.87$ & $32.3 \pm 3.63$ & 76.10 & 16.67 \\
PGE & $100 \mathrm{mg} / \mathrm{kg}$ & $41.4 \pm 1.80$ & $27.4 \pm 2.78$ & 62.41 & $31.66^{*}$ \\
PGE & $200 \mathrm{mg} / \mathrm{kg}$ & $42.0 \pm 1.92$ & $21.5 \pm 1.66$ & 47.83 & $47.62^{*}$ \\
PGE & $400 \mathrm{mg} / \mathrm{kg}$ & $40.7 \pm 1.75$ & $15.1 \pm 1.25$ & 32.56 & $64.35^{\star *}$ \\
Atropine & $1 \mathrm{mg} / \mathrm{kg}$ & $41.3 \pm 1.56$ & $12.3 \pm 0.56$ & 24.64 & $73.02^{\star *}$ \\
\hline
\end{tabular}

One-way ANOVA + Dunnett's post-hoc test, $\mathrm{n}=6 .{ }^{*}, P<0.05 ;{ }^{* \star}, P<0.01$ vs. control. Mean \pm SEM.

the propulsive movement and transit of charcoal meal through the small intestine. Loperamide $(10 \mathrm{mg} / \mathrm{kg}$, p.o.) produced greater anti-motility effect than the highest dose of PGE $(400 \mathrm{mg} / \mathrm{kg}$, p.o.) used (Table 3).

\section{Intestinal motility and transit in mice (charcoal study)}

Compared with the 'control' group of animals, in the treated 'test' groups of mice, PGE (50, $100,200$ and $400 \mathrm{mg} / \mathrm{kg}$, p.o. $)$ dose-dependently and significantly $(P<0.05-0.01)$ decreased the propulsive movement and transit of charcoal meal through the gastrointestinal tract (GIT). Atropine sulphate $(1 \mathrm{mg} / \mathrm{kg}$, p.o. $)$ produced greater antimotility effect than the highest dose of PGE (400 mg/kg, p.o.) used (Table 4).

\section{Castor oil-induced enteropooling in rats}

Oral administration of castor oil $(3 \mathrm{ml} / \mathrm{kg}$, p.o. $)$ produced a marked and significant $(P<0.01)$ increase in the intestinal fluid volume of castor oil-treated groups of rats compared to 'control' group of animals treated with distilled water $(10 \mathrm{ml} / \mathrm{kg}$, p.o. $)$ only. Compared with the 'control' group of rats, pretreatment of the 'test' groups of rats with PGE (50,100, 200 and $400 \mathrm{mg} / \mathrm{kg}$, p.o.) dose-dependently and significantly $(P<0.05-0.01)$ inhibited castor oil-induced fluid accumulation in rats (Table 5). The standard antidiarrhoeal drug, loperamide $(10 \mathrm{mg} / \mathrm{kg}$, p.o. $)$, produced a more marked and significantly greater $(P<0.001)$ inhibitory effects on castor oil- 
Table 5. Effects of Psidium guajava leaf aqueous extract (PGE, 50-400 mg/kg, p.o.) on castor oil-induced intestinal enteropooling and fluid accumulation in rats

\begin{tabular}{lccc}
\hline $\begin{array}{c}\text { Treatment intestinal } \\
\text { fluid group }\end{array}$ & $\begin{array}{c}\text { Dose } \\
(\mathrm{mg} / \mathrm{kg}, \text { p.o. })\end{array}$ & $\begin{array}{c}\text { Intestinal fluid (ml) } \\
{[\text { Mean }( \pm \mathrm{SEM})]}\end{array}$ & $\begin{array}{c}\text { \% Inhibition of } \\
\text { volume }(\mathrm{ml})\end{array}$ \\
\hline $\begin{array}{l}\text { Control } \\
\text { (Castor oil) }\end{array}$ & & $5.6 \pm 1.7$ & 0.0 \\
Castor oil (3 ml/kg)+ & & $5.3 \pm 1.1$ & 5.4 \\
Distilled water & & $4.5 \pm 0.8$ & 19.6 \\
PGE & $50 \mathrm{mg} / \mathrm{kg}$ & $3.6 \pm 0.6$ & $35.7^{*}$ \\
PGE & $100 \mathrm{mg} / \mathrm{kg}$ & $2.7 \pm 0.5$ & $51.8^{* *}$ \\
PGE & $200 \mathrm{mg} / \mathrm{kg}$ & $1.4 \pm 0.2$ & $75.0^{* *}$ \\
PGE & $400 \mathrm{mg} / \mathrm{kg}$ & $0.6 \pm 0.1$ & $89.3^{* * *}$ \\
Loperamide & $10 \mathrm{mg} / \mathrm{kg}$ & &
\end{tabular}

One-way ANOVA + Dunnett's post-hoc test, $\mathrm{n}=6$. ${ }^{*}, P<0.05 ;{ }^{* *}, P<0.01 ;{ }^{* \star *}, P<0.001$ vs. control.

induced fluid accumulation than the highest dose of PGE (400 mg/kg, p.o.) used (Table 5). The intestinal fluids of the animals pretreated with the aqueous extract (PGE) and loperamide were found to be more viscous than those of the distilled water-treated 'control' rats.

\section{Discussion}

The $\mathrm{LD}_{50}$ value of $1,534 \pm 69 \mathrm{mg} / \mathrm{kg}$, i.p., obtained for PGE in the mice used for acute toxicity study probably suggests that the plant's extract is relatively safe in, or non-toxic to, mice. However, the results of the present laboratory animal study indicate that Psidium guajava leaf aqueous extract (PGE) possesses antidiarrhoeal activity in rodents. The findings of the present study confirm the observations, and extend earlier studies on, antidiarrhoeal properties reported for Psidium guajava species by Olajide et al. (1999), Lin et al. (2002) and Lozoya et al. (2002). Previous studies in our laboratories and elsewhere have also reported antidiabetic, hypoglycaemic, antiinflammatory and analgesic (Ojewole, 2005; 2006), antibacterial (Lutterodt $e t$ al., 1999; Vieira et al., 2001; Arima and Danno, 2002; Gonçalves et al., 2008; Gutiĕrrez et al., 2008), anti-cancer (Teixeira et al., 2003; Gutiěrrez et al., 2008), antioxidant (Qian and Nihorimbere, 2004; Gutiěrrez et al., 2008), anti-spasmodic (Lozoya et al., 2002), and other pharmacological effects (Gutiĕrrez et al., 2008) of Psidium guajava extracts in various experimental animal paradigms.

PGE (50-400 mg/kg, p.o.) dose-dependently and significantly inhibited all the diarrhoeal parameters (onset, frequency and severity of diarrhoea, total number of stools, number of wet stools, weight of wet stools, etc) measured. Furthermore, the extract dose-dependently and significantly decreased normal intestinal propulsive movement and transit in rodents. The percentage inhibition by the highest dose of PGE (400 mg/kg, p.o.) used was, however, lower than those of the standard antidiarhoeal drugs, loperamide $(10 \mathrm{mg} / \mathrm{kg}$, p.o. $)$ and atropine (1 $\mathrm{mg} / \mathrm{kg}$, p.o.) employed. Loperamide and atropine inhibited gastrointestinal motility (propulsion), reduced intestinal fluid secretion and accumulation, and delayed gastric emptying, thus ameliorating diarrhoea.

Castor oil is known to cause water and electrolyte permeability changes in the intestinal 
mucosal membranes, resulting in fluid and watery luminal contents that flow rapidly through the small and large intestines (Gaginella et al., 1975; Mbagwu and Adeyemi, 2008). In castor oilinduced diarrhoeic animals, PGE dose-dependently and significantly delayed the onset of copious diarrhoea, decreased the frequency of purging, reduced the number and weight of wet stools, and inhibited the severity of diarrhoea (diarrhoea score) generally. In the enteropooling study, the plant's extract dose-dependently and significantly reduced both the weight and volume of the animals' intestinal contents. The intraluminal fluid accumulation induced by castor oil was blocked by the extract in a dose-related manner.

Clinically, diarrhoea may result from disturbed bowel function, in which case, there is impaired intestinal absorption, excessive intestinal secretion of water and electrolytes, and a rapid bowel transit (Gurgel et al., 2001; Mbagwu and Adeyemi, 2008). Bacterial (microbial) infection could also impair bowel function and give rise to dysentery and/or diarrhoea. According to Mbagwu and Adeyemi (2008), antidiarrhoeal index (ADI) is a measure of the combined effects of the different components of diarrhoea, including purging frequency, onset of diarrhoeal stools, and frequency of intestinal movement. The antibacterial activity earlier reported for PGE by Lutterodt et al. (1999), Vieira et al. (2001), Arima and Danno (2002) and Gonçalves et al. (2008) would, therefore, appear to be useful in combating diarrhoea (or dysentery) of bacterial origin.

Activation of the sympathetic innervation of the intestine results in inhibition of peristaltic activity and a reduction in tone. Recent studies in our laboratories have shown that PGE induced concentration-related inhibitions of the spontaneous, rhythmic, peristaltic contractions of rabbit isolated duodenum, and relaxed the muscle like noradrenaline (Chiwororo and Ojewole, unpublished preliminary observation). Furthermore, it has been observed that PGE relaxed guinea-pig isolated ileum in a concentration-related manner, and antagonized acetylcholine $(\mathrm{ACh})$-induced contractions of the ileum in a concentration-dependent manner, like atropine (Chiwororo and Ojewole, unpublished preliminary observation). These preliminary observations tend to suggest that the anti-motility effect of PGE could be partly mediated via activation of alpha ${ }_{2}$-adrenoceptors, and/or blockade of muscarinic cholinoceptors on mammalian intestine. The possibility also exists that muscarinic cholinoceptor antagonists (such as atropine) can synergistically potentiate the antidiarrhoeal effect of PGE by enhancing the extract's effect on both intestinal secretion and motility.

The remarkable dose-related reductions in castor oil-induced diarrhoea produced by PGE in mice and rats is a clear evidence of the antidiarrhoeal efficacy of the extract, although the highest dose of PGE (400 mg/kg, p.o.) used in the rodents produced less antidiarrhoeal activity when compared with loperamide $(10 \mathrm{mg} / \mathrm{kg}$, p.o.), a standard anti-diarrhoeal drug. Atropine (1 $\mathrm{mg} / \mathrm{kg}$, p.o.), an antimuscarinic drug, and different doses of PGE (50, 100, 200 and $400 \mathrm{mg} / \mathrm{kg}$, p.o.) decreased propulsive movements in the charcoal meal study, the extract being less potent than atropine. The significant inhibition of the castor oil-induced enteropooling by PGE in mice suggests that the extract probably produces relief in diarrhoea through its spasmolytic and antienteropooling effects. These findings are in consonance with the observations reported by Abdullahi et al. (2001) for aqueous root extract of Terminalia avicennoides (Combretaceae); Aniagu et al. (2005) for aqueous root extract of Guiera senegalensis (Combretaceae), Akindele 
and Adeyemi (2006) for aqueous leaf extract of Byrsocarpus coccineus (Connaraceae), and Mbagwu and Adeyemi (2008) for aqueous whole plant extract of Mezoneuron benthamianum (Fabaceae).

Although the exact mechanism of the antidiarrhoeal action of PGE could not be established in this study, a number of investigators have shown that tannins and other polyphenolic compounds (e.g., coumarins), flavonoids, triterpenoids, saponins, and a host of other plant secondary metabolites possess antidiarrhoeal properties in various experimental animal models (Dicarlo et al., 1994; Abdullahi et al., 2001; Aniagu et al., 2005; Agunu et al., 2005; Akindele and Adeyemi, 2006; Suleiman et al., 2008; and Mbagwu and Adeyemi, 2008). Since Psidium guajava is known to contain beta-sitosterol, uvaol, numerous tannins, polyphenolic compounds, pentacyclic triterpenoids (including guajanoic acid, oleanolic and ursolic acids), ellagic acid, guiajaverin, quercetin and other flavonoids (Watt and Breyer-Brandwijk, 1962; Dicarlo et al., 1994; Van Wyk et al., 2002; Van Wyk, and Wink, 2004), it is not unreasonable to speculate that some of these chemical compounds, especially the flavonoids, coumarins and pentacyclic triterpenoids, could have contributed to the observed antidiarrhoeal effect of the plant's leaf aqueous extract. Quercetin, a prominent constituent of Psidium guajava leaf, has been shown to inhibit spasmogenic effects of various agonists (acetylcholine, carbachol, potassium chloride, etc) on guinea-pig isolated ileum (Gălvez et al., 1996). The flavonoid has also been shown to inhibit gastrointestinal release of acetylcholine ((Lutterodt, 1989). Furthermore, it has been suggested that quercetin exerts its spasmolytic (i.e., antispasmodic) effect via calcium antagonism (Morales et al., 1994). Taken together, we speculate that PGE probably produces antidiarrhoeal activity through a combination of its antibacterial (antimicrobial) property and its ability to inhibit gastrointestinal acetylcholine release. However, further studies are required to clarify this speculation.

In conclusion, experimental evidence obtained in the present laboratory animal study indicates that PGE possesses antidiarrhoeal activity. This finding lends pharmacological credence to the anecdotal, ethnomedical use of Psidium guajava leaf as a natural remedy for the treatment, management and/or control of diarrhoea in some rural communities of southern Africa.

\section{Acknowledgements}

The authors are grateful to Mrs. Nirasha Nundkumar for her assistance in the extraction of Psidium guajava leaf, and to Miss Kogi Moodley for her technical assistance. A part of this study was carried out by Dr. E. O. Awe in the Department of Pharmacology and Therapeutics, College of Medicine, University of Ibadan, Ibadan, Nigeria.

\section{References}

Abdullahi, A.L., Agho, M.O., Amos, S., Gamaniel, K.S. and Wambebe, C. (2001). Antidiarrhoeal activity of the aqueous extract of Terminalia avicennoides roots. Phytotherapy Res. 15: 431-434.

Adeyemi, O.O. and Akindele, A.J. (2008). Antidiarrhoeal activity of the ethyl acetate extract of Baphia 
nitida (Papilionaceae). J. Ethnopharmacol. 116: 407-412.

Agunu, A., Yusuf, S., Andrew, G.O., Zezi, A.U. and Abdurahman, E.M. (2005). Evaluation of five medicinal plants used in diarrhoea treatment in Nigeria. J. Ethnopharmacol. 101: 27-30.

Akindele, A.J. and Adeyemi, O.O. (2006). Evaluation of the antidiarrhoeal activity of Byrsocarpus coccineus. J. Ethnopharmacol. 108: 20-25.

Aniagu, S.O., Binda, L.G., Nwinyi, F.C., Orisadipe, A., Amos, S., Wambebe, C. and Gamaniel, K. (2005). Anti-diarrhoeal and ulcer-protective effects of the aqueous root extract of Guiera senegalensis in rodents. J. Ethnopharmacol. 97: 549-554.

Arima, H. and Danno, G. (2002). Isolation of antimicrobial compounds from guava (Psidium guajava L.) and their structural elucidation. Biosci. Biotechnol. Biochem. 66: 1727-1730.

Avery, M.E. and Synder, J.D. (1990). Oral therapy for acute diarrhoea. Antenn. J. Med. 323: 891-894.

Awouters, F., Niemegeers, C.J.E., Lenaerts, F.M. and Janssen, P.A.J. (1978). Delay of castor oil diarrhoea in rats: a new way to evaluate inhibitors of prostaglandin biosynthesis. J. Pharm. Pharmacol. 30: 41-45.

Aye-Than, J.H., Kulkarni, W. and Tha, S.J. (1989). Antidiarrhoeal efficacy of some Burmese indigenous drug formulations in experimental diarrhoea models. Internat. J. Crude Drug Res. 27: 195-200.

Brunton, L.L. (1996). Agents for control of gastric acidity and treatment of peptic ulcers. In: Goodman and Gilman's 'The Pharmacological Basis of Therapeutics', 9th ed., McGaw-Hill, New York, pp. 901-915.

Dicarlo, G.D., Mascolo, N., Izzo, A.A., Capasso, F. and Autore, G. (1994). Effects of quercetin on gastrointestinal tract in rats and mice. Phytotherapy Res. 8: 42-45.

Dunnett, C. and Goldsmith, C. (1993). In: Statistics in the Pharmaceutical Industry, 2nd ed., ed. by C.R. Buncher and J.Y. Tsay, Marcel Dekker, New York.

Field, M., Rao, M.C. and Chang, E.B. (1989). Intestinal electrolyte transport and diarrhoea disease. New England J. Med. 321: 800-806.

Fontaine, O. (1988). Bacterial diarrhoea and treatment. Lancet 331: 1234-1235.

Gaginella, T. S., Stewart, J.J., Olsen, W.A. and Bass, P. (1975). Action of ricinoleic acid and structurallyrelated fatty acid on gastrointestinal tract. II. Effect on water and electrolyte absorption in vitro. J. Pharmacol. Exp. Ther. 195: 355-361.

Gălvez, J., Duarte, J., Medina, F.S., Jimĕnez, J. and Zarzuelo, A. (1996). Inhibitory effects of quercetin on guinea-pig ileum contractions. Phytotherapy Res. 10: 66-69.

Gamaniel, K.S. and Akah, P.A. (1996). Analysis of the gastrointestinal relaxing effect of the stem-bark extract of Gongronema latifolium. Phytomed. 2: 293-296.

Gonçcalves, F.A., Andrade-Neto, M., Bezerra, J.N.S., Macrae, A., Sousa, O.V., Fonteles-Filho, A.A. and Vieira, R.H.S.F. (2008). Antibacterial activity of guava, Psidium guajava Linnaeus, leaf extracts on diarrhoea-causing enteric bacteria isolated from Seabob shrimp, Xiphopenaeus kroyeri (Heller). Rev. Inst. Med. Trop. S. Paulo 50: 11-15.

Gurgel, L.A., Silva, R.M., Santos, F.A., Martins, D.T.O., Mattos, P.O. and Rao, V.S.N. (2001). Studies on the antidiarrhoeal effect of dragon's blood from Croton Urucarana. Phytotherapy Res. 15: 319322.

Gutiĕrrez, R.M.P., Mitchell, S. and Solis, R.V. (2008). Psidium guajava: a review of its traditional uses, phytochemistry and pharmacology. J. Ethnopharmacol. 117: 1-27.

Hirchhorn, N. (1980). The treatment of acute diarrhoea in children: an historical and physiological perspective. Am. J. Clinic. Nutrit. 33: 637-663.

Longe, R.L. and Dipiro, J.T. (1992). Diarrhoea and constipation. In: Pharmacotherapy: A Pathophysiologic Approach, 2nd ed., ed. by J.T. Dipiro, R.L. Talbert and P.E. Hayes, Elsevier, New York, pp 566-578.

Lin, J., Puckree, T. and Mvelase, T.P. (2002). Anti-diarrhoeal evaluation of some medicinal plants used by Zulu traditional healers. J. Ethnopharmacol. 79: 53-56. 
Lorke, D. (1983). A new approach to practical acute toxicity testing. Arch. Toxicol. 54: 275-287.

Lozoya, X., Reyes-Morales, H., Chăvez-Soto, M.A., Martı̆nez-Garcĭa, M.C., Soto-Gonzălez, Y. and Doubova, S.V. (2002). Intestinal anti-spasmodic effect of a phytodrug of Psidium guajava folia in the treatment of acute diarrhoeic disease. J. Ethnopharmacol. 83: 19-24.

Lutterodt, G.D. (1989). Inhibition of gastrointestinal release of acetylcholine by quercetin as a possible mode of action of Psidium guajava leaf extracts in the treatment of acute diarrhoeal disease. $J$. Ethnopharmacol. 25: 235-247.

Lutterodt, G.D., Ismail, A., Basheer, R.H. and Baharudin, H.M. (1999). Antimicrobial effects of Psidium guajava extract as one mechanism of its antidiarrhoeal action. Malaysian J. Med. Sci. 6: 17-20.

Mbagwu, H.O.C. and Adeyemi, O.O. (2008). Anti-diarrhoeal activity of the aqueous extract of Mezoneuron benthamianum Baill (Caesalpinaceae). J. Ethnopharmacol. 116: 16-20.

Morales, M.A., Tortoriello, J., Meckes, M., Paz, D. and Loxoya, X. (1994). Calcium-antagonist effect of quercetin and its relation with the spasmolytic properties of Psidium guajava L. Arch. Med. Res. 25: $17-21$.

Mukherjee, P.K., Scha, K., Murugesan, T., Mandal, S.C., Pal, M. and Scha, B.P. (1998). Screening of antidiarrhoeal profiles of some plant extracts of specific regions of West Bengal, India. $J$. Ethnopharmacol. 60: 85-89.

Ojewole, J.A.O. (2005). Hypoglycaemic and hypotensive effects of Psidium guajava Linn. (Myrtaceae) leaf aqueous extract. Meth. Find. Exp. Clinic. Pharmacol. 27: 689-695.

Ojewole, J.A.O. (2006). Anti-inflammatory and analgesic effects of Psidium guajava Linn. (Myrtaceae) leaf aqueous extract in rats and mice. Meth. Find. Exp. Clinic. Pharmacol. 28: 441-446.

Olajide, O.A., Awe, S.O. and Makinde, J.M. (1999). Pharmacological studies on the leaf of Psidium guajava. Fitoterapia 70: 25-31.

Qian, H. and Nihorimbere, V. (2004). Antioxidant power of phytochemicals from Psidium guajava leaf. J. Science 5: 676-683.

Snyder, J.D. and Merson, M.H. (1982). The magnitude of the global problem of acute diarrhoeal disease: a review of acute surveillance data. Bull. World Health Organiz. 60: 604-613.

Suleiman, M.M., Dzenda, T. and Sani, C.A. (2008). Antidiarrhoeal activity of the methanol stem-bark extract of Annona senegalensis Pers. (Annonaceae). J. Ethnopharmacol. 116: 125-130.

Teixeira, R.O., Camparoto, M.L., Mantovani, M.S. and Vicentini, V.E.P. (2003). Assessment of two medicinal plants, Psidium guajava L. and Achillea millefolium L., in in vitro and in vivo assays. Genet. Mol. Biol. 26: 551-555.

Van Wyk, B-E. and Wink, M. (2004). Medicinal Plants of the World, 1st ed., Briza Publications, Pretoria (South Africa), p. 258.

Van Wyk, B-E., Van Oudtshoorn, B. and Gericke, N. (2002). Medicinal Plants of South Africa, 2nd ed., Briza Publications, Pretoria, pp. 202-203.

Venkatesan, N., Thiyagarajan, V., Narayanan, S., Arul, A., Raja, S., Kumar, S.G.V., Rajarajan, T. and Perianayagam, J.B. (2005). Antidiarrhoeal potential of Asparagus racemosus wild root extracts in laboratory animals. J. Pharmacol. Pharm. Sci. 8: 39-45.

Vieira, R.H.S.F., Rodrigues, D.P., Gonçalves, F.A., Menezes, F.G. R., Aragăo, J.S. and Sousa, O.V. (2001). Microbicidal effect of medicinal plant extracts (Psidium guajava Linn. and Carica papaya Linn.) upon bacteria isolated from fish muscle and known to induce diarrhoea in children. Rev. Inst. Med. Trop. S. Paulo 43: 145-148.

Watt, J.M. and Breyer-Brandwijk, M.G. (1962). Medicinal and Poisonous Plants of Southern and Eastern Africa, 2nd ed., E. \& S. Livingstone Ltd., Edinburgh and London, pp. 798-799. 